IZA DP No. 9416

Is Economics a Good Major for Future Lawyers?

Evidence from Earnings Data

John V. Winters

October 2015 


\title{
Is Economics a Good Major for Future Lawyers? Evidence from Earnings Data
}

\author{
John V. Winters \\ Oklahoma State University \\ and IZA
}

Discussion Paper No. 9416

October 2015

\author{
IZA \\ P.O. Box 7240 \\ 53072 Bonn \\ Germany \\ Phone: +49-228-3894-0 \\ Fax: +49-228-3894-180 \\ E-mail: iza@iza.org
}

\begin{abstract}
Any opinions expressed here are those of the author(s) and not those of IZA. Research published in this series may include views on policy, but the institute itself takes no institutional policy positions. The IZA research network is committed to the IZA Guiding Principles of Research Integrity.

The Institute for the Study of Labor (IZA) in Bonn is a local and virtual international research center and a place of communication between science, politics and business. IZA is an independent nonprofit organization supported by Deutsche Post Foundation. The center is associated with the University of Bonn and offers a stimulating research environment through its international network, workshops and conferences, data service, project support, research visits and doctoral program. IZA engages in (i) original and internationally competitive research in all fields of labor economics, (ii) development of policy concepts, and (iii) dissemination of research results and concepts to the interested public.
\end{abstract}

IZA Discussion Papers often represent preliminary work and are circulated to encourage discussion. Citation of such a paper should account for its provisional character. A revised version may be available directly from the author. 
IZA Discussion Paper No. 9416

October 2015

\section{ABSTRACT \\ Is Economics a Good Major for Future Lawyers? Evidence from Earnings Data*}

The current study examines earnings differences for practicing lawyers by undergraduate major with a focus on economics majors. Some majors do much better than others. Economics majors tend to do very well in both median and mean earnings, and both without and with controlling for individual characteristics. Electrical engineering, accounting, finance, and some other majors also do relatively well. This information is useful for undergraduates planning to attend law school and considering what undergraduate major field to study. Economics appears to be a very good option.

JEL Classification: I20, I26, J24, J31

Keywords: college major, earnings, economics major, lawyers, attorneys

Corresponding author:

John V. Winters

Oklahoma State University

331 Business Building

Stillwater, OK 74078-4011

USA

E-mail: jvwinte@okstate.edu

\footnotetext{
* The author thanks Lee Adkins, James Bishop, Jim Fain, and Laurie Lucas for helpful comments. Any errors, omissions or opinions are solely the responsibility of the author.
} 


\section{INTRODUCTION}

Each year millions of young college students around the world face an important decision that will significantly impact the rest of their life, the choice of what major field of study to pursue. Economists have much to say about how young people make this decision. The human capital framework suggests that young people weigh the present and future costs and benefits of various fields of study. Rational decision makers will choose the major field of study that offers them the highest expected utility. Of course, the expected benefits and costs vary across individuals due to different skills, endowments, and preferences. By far one of the most important benefits offered by various majors is the expected future earnings, and economics has consistently been shown to be a financially rewarding major (Black et al. 2003; Allgood et al. 2011; Carroll et al. 2014; Winters and Xu 2014). However, expected earnings also depend on the career path an individual plans to pursue after college. For a given major, some occupations will pay much higher and some much lower than the average earnings for the major as a whole. Similarly, for a given occupation, some majors will offer much higher and some much lower earnings than the average for the occupation.

Many young people already have a specific occupation path in mind and then choose a major that they believe will help prepare them for that career. This is especially true among students interested in becoming lawyers. Law schools admit students from a wide variety of backgrounds, but some majors are certainly more popular than others among law school applicants. Similarly, there is some belief that some majors provide especially good preparation for law school, for example, by developing familiarity with the legal system, reading and writing skills, analytical thinking, logical reasoning, and argument construction. Furthermore, some 
majors are thought be especially well-suited for preparing for the Law School Admission Test (LSAT), which plays a major role in law school admissions decisions.

Economists and others have frequently noted that economics majors tend to have well above average LSAT scores and often the highest among large majors (Nieswiadomy 1998, 2006, 2010, 2014). However, evidence of college major effects on other legal education and career outcomes is much rarer. Notable exceptions are Craft and Baker (2003) and Black et al. (2003), both of which examine the effects of majoring in economics and a few other fields on the earnings of lawyers using the 1993 National Survey of College Graduates (NSCG). Among the college major groups considered ${ }^{1}$, economics majors have the highest mean earnings and this advantage persists even after controlling for observable individual characteristics via linear regression. Their results suggest that economics is good preparation for a legal career even beyond the effects of economics on LSAT scores. ${ }^{2}$

The current paper extends the previous literature by examining the effects of college major, focusing on a major in economics, on the earnings of practicing lawyers. The major contribution relative to Craft and Baker (2003) and Black et al. (2003) is the use of a much newer and larger dataset. Specifically, the data are from the pooled 2009-2013 American Community Survey, which provides a five percent sample of the U.S. population. I also examine both mean and median earnings. The results indicate some moderate differences from previous studies, but the main result is quite consistent. Economics is a well-paying undergraduate

\footnotetext{
${ }^{1}$ Unfortunately, the relatively small size of the NSCG limits the analyses to relatively large majors to avoid considerable imprecision from very small majors. Craft and Baker (2003) examine a sample of 2072 observations and include only 10 majors/majors group; these are economics, political science, history, prelaw, accounting, science and engineering, other social sciences, other business fields, education and humanities, and all other fields. Black et al. (2003) include 2152 observations and focus on the 12 individual majors that have at least 30 individual observations in the 1993 NSCG, which includes economics, criminology, accounting, business administration, finance, history, political science, psychology, sociology, English, foreign language, and philosophy \& theology. ${ }^{2}$ Craft and Baker (2003) also suggest that among college majors that typically score highly on the LSAT, only economics was also found to offer high earnings among lawyers.
} 
college major for future lawyers. This information should be useful to undergraduates interested in law school and considering majoring in economics.

\section{THE DATA}

Each year the American Community Survey (ACS) samples one percent of the U.S. population and asks about various household, demographic, education, employment, income, and occupational topics. Since 2009 the ACS has asked individuals who have obtained a bachelor's degree or higher to report the major field of study for their undergraduate degree. The current study examines differences in the annual earnings of practicing lawyers by undergraduate college major using the combined 2009-2013 ACS. The data were obtained from IPUMS (Ruggles et al. 2015). Lawyers are defined based on reported occupation. ${ }^{3}$ The ACS does not identify persons with law degrees working in other occupations. A few observations are also excluded who report working as lawyers but report their highest education as less than a professional degree. The ACS questionnaire is explicit that a JD is a professional degree and a higher education level than a bachelor's or a master's degree. The initial sample is also limited to persons ages 25-61. Persons older than age 61 may be affected by early retirement and those younger than age 25 are rarely old enough to have completed law school.

Annual earnings in the ACS are reported to reflect the earnings in the previous 12 months. The ACS surveys people throughout a year, but one cannot identify the month of the survey, only the year. All earnings are adjusted for inflation using the annual consumer price index (CPI) produced by the Bureau of Labor Statistics and are reported in January 2015 dollars. Because many people do not finish law school and begin working until well after age 25 , the

\footnotetext{
${ }^{3}$ Specifically, I use the IPUMS occ1990 variable and restrict the sample to persons with occ1990 code 178.
} 
earnings sample is limited to ages 30-61. Of course, some people finish law school even after age 30, but the ACS does not identify when an individual earned their highest degree or began working as a lawyer. Age 30 was chosen as the lower bound to keep the sample as large as possible while minimizing the effects of very new lawyers with less than 12 months in the lawyer occupation on average earnings.

Table 1 examines which undergraduate majors are popular among practicing lawyers in the ACS. ${ }^{4}$ The 25 most popular majors are listed and ranked by size along with the percentages of all lawyers that the majors make up. Political science is the most common major among practicing lawyers, accounting for 21.6 percent of all lawyers. Economics is fourth in size and accounts for 6.5 percent of the total. History, English, and Psychology round out the top five in size. Size ranks 6-10 include business management, accounting, general business, philosophy and religion, and finance. The top 25 majors collectively account for 84.7 percent of all practicing lawyers, and the top five majors alone account for 50.9 percent.

\section{MEDIAN AND MEAN LAWYER EARNING BY MAJOR}

Table 2 reports median and mean lawyer earnings by major for the 25 most popular undergraduate majors from Table 1. Smaller majors are of less interest and generally have too few observations in the sample to produce reliable estimates. Table 2 also ranks majors by median and mean earnings. Because these measures are for ages 30-61, they are certainly not starting salaries. They instead illustrate the typical annual earnings one might expect over a career. Additionally, these summary measures are not just restricted to wage and salary employees. They include the full earnings of all lawyers including those who are self-employed

\footnotetext{
${ }^{4}$ The ACS college major codes were combined for economics (5501) and business economics (6205) to form a single group for economics. History (6402) and U.S. history (6403) were also combined to form one group.
} 
sole-proprietors and those who are partners in multi-proprietor firms. Furthermore, the data do not allow one to differentiate by field of practice or law school attended. So there are some certainly some caveats, but the information is likely insightful nonetheless.

Mean annual earnings for lawyers exceed \$100,000 for all 25 majors in Table 2, and median earnings exceed $\$ 100,000$ for 20 of the 25 . Thus, practicing lawyers tend to have generally good earnings prospects. Mean earnings also substantially exceed the median for all 25 majors, suggesting that mean lawyer earnings are somewhat skewed by a few lawyers who earn very high incomes. Consequently, median earnings might be the preferred measure to assess what a typical graduate might earn. Thus, Table 2 is sorted by median earnings and lists median earnings first. However, the rankings are quite consistent between median and mean earnings. Those majors with high median earnings have high mean earnings and vice versa. Lawyers with undergraduate majors in electrical engineering have the highest earnings according to both medians $(\$ 179,744)$ and means $(\$ 219,383)$. Electrical engineering is not a very common route to law school as indicated in Table 1 , which shows it as only the $22^{\text {nd }}$ most popular major among practicing lawyers in the ACS. The high earnings for electrical engineering may result from having specialized knowledge that is valuable in particular fields in high demand. For example, engineering knowledge may be especially useful in patent law, due to the needs to precisely and accurately specify technical processes and product attributes.

Accounting majors have the second highest median $(\$ 135,044)$ and third highest mean $(\$ 180,507)$ earnings. Economics majors have the third highest median $(\$ 130,723)$ and the second highest mean $(\$ 182,359)$ earnings. Finance has the fourth highest median $(\$ 122,150)$ and mean $(\$ 170,356)$ earnings. Thus, these three relatively quantitative business-related fields do quite well. This may be somewhat attributable to these majors working in areas of law that are 
especially lucrative, e.g., mergers and acquisitions. Chemistry is fifth in mean and sixth in median earnings, while mathematics if sixth in mean and fifth in median earnings.

\section{REGRESSION ANALYSIS}

The medians and means in Table 2 provide very interesting descriptive information but they may not represent causal estimates on earnings from majoring in a specific field. Individuals differ in both observable and unobservable dimensions that affect their undergraduate major, their decision to practice law, the type of law to practice, where to practice, and their earning potential. Data limitations do not allow one to control for all of these things, but some observable characteristics can be controlled for using regression analysis. Table 3 presents results from median regression and ordinary least squares (OLS) regression of log earnings on dummy variables for college major, while controlling for observable individual characteristics. The use of log earnings is standard in the earnings literature and allows coefficients to be interpreted roughly as percentage changes.

The controls include dummies for sex, race/ethnicity, age, survey year, and area of current residence. The demographic controls are very common in the literature. Year dummies are included to account for aggregate trends over time. Current residence is defined as the metropolitan areas for those living in identifiable metropolitan areas and as state residual areas otherwise. Location has been shown to be a major determinant of earnings in general and for specific majors and should be controlled for when possible (Winters and Wu 2014). Many interesting and potentially important variables are unavailable and college majors are not randomly assigned, so the estimates should still be interpreted with some caution. 
Table 3 reports median regression coefficients in column 1 and OLS regression coefficients in column 2 for the college major dummies. Median and OLS regression coefficient estimates do vary somewhat but are often quite similar. Results for the control variables are not reported but are available from the author by request. The majors in Table 3 are sorted by median regression coefficients from high to low. Undergraduate economics majors are defined to be the omitted base group. Coefficient estimates for the other majors should be interpreted relative to economics. Electrical engineering has the highest coefficient for both median and OLS regression and has statistically significantly higher earnings than economics. The median (OLS) regression coefficient of $0.230(0.183)$ suggests that electrical engineering has median (mean) earnings roughly 23.0 (18.3) percent greater than economics. No other major has median earnings statistically significantly greater than economics, and accounting is the only other major with significantly (at the ten percent level) greater mean earnings than economics. In total, three majors have positive median earning coefficients, while 21 majors have negative median coefficients, 18 of which are statistically significant. For OLS, 17 majors have earnings that are significantly less than economics. Thus, even after using regression to control for individual characteristics, economics still has quite good median and mean earnings relative to other majors.

\section{CONCLUSION}

The current study examines earnings differences across undergraduate majors for practicing lawyers in the U.S. with a focus on economics majors. Obtaining unbiased causal estimates is potentially precluded by non-random assignment, self-selection, and omitted variables. However, the descriptive analysis in this paper has the potential to illustrate the 
benefits of various undergraduate majors for students interested in pursuing a career in law. Some majors do much better than others. Of interest to economics faculty, economics majors tend to do very well in both median and mean earnings, and both without and with controls for individual characteristics. Thus, economics is a high paying undergraduate major for those who later practice law. This is useful information for undergraduates planning to attend law school and considering economics as an undergraduate major. Sharing this information with interested students may help economics faculty and departments illustrate some of the many benefits of majoring in economics. 


\section{REFERENCES}

Allgood, S., W. Bosshardt, W. H. Van der Klaauw, and M. Watts. 2011. Economics course work and long-term behavior and experiences of college graduates in labor markets and personal finance. Economic Inquiry 49: 774-94.

Black, D., S. Sanders, and L. Taylor. 2003. The economics reward for studying economics. Economic Inquiry 41: 365-77.

Carroll, T., D. Assane, and J. Busker. 2014. Why it pays to major in economics. Journal of Economic Education 45: 251-61.

Craft, R. K., and J. G. Baker. 2003. Do economists make better lawyers? Undergraduate degree field and lawyer earnings. Journal of Economic Education 34: 263-81.

Nieswiadomy, M. 1998. LSAT scores of economics majors. Journal of Economic Education 29: $377-79$.

Nieswiadomy, M. 2006. LSAT scores of economics majors: The 2003-2004 class update. Journal of Economic Education 37: 244-47.

Nieswiadomy, M. 2010. LSAT scores of economics majors: The 2008-9 class update. Journal of Economic Education 41: 331-33.

Nieswiadomy, M. 2014. LSAT scores of economics majors: The 2012-2013 class update. Journal of Economic Education 45: 71-74.

Ruggles, S., K. Genadek, R. Goeken, J. Grover, and M. Sobek. 2015. Integrated Public Use Microdata Series: Version 6.0 [Machine-readable database]. Minneapolis: University of Minnesota.

Winters, J. V., and W. Xu. 2014. Geographic differences in the earnings of economics majors. Journal of Economic Education 45: 262-76. 
Table 1: The 25 Most Popular College Majors Among Lawyers in the ACS

\begin{tabular}{lcc}
\hline Major & $\begin{array}{c}\text { Size } \\
\text { Rank }\end{array}$ & $\begin{array}{c}\text { Percentage of All } \\
\text { Practicing Lawyers }\end{array}$ \\
\hline Political Science and Government & 1 & $21.58 \%$ \\
History & 2 & $9.90 \%$ \\
English Language and Literature & 3 & $8.05 \%$ \\
Economics & 4 & $6.51 \%$ \\
Psychology & 5 & $4.83 \%$ \\
Business Management and Administration & 6 & $3.82 \%$ \\
Accounting & 7 & $2.80 \%$ \\
General Business & 8 & $2.78 \%$ \\
Philosophy and Religious Studies & 9 & $2.77 \%$ \\
Finance & 10 & $2.34 \%$ \\
Criminal Justice and Fire Protection & 11 & $2.33 \%$ \\
Sociology & 12 & $2.13 \%$ \\
Communications & 13 & $1.86 \%$ \\
Biology & 14 & $1.83 \%$ \\
Journalism & 15 & $1.50 \%$ \\
Liberal Arts & 16 & $1.30 \%$ \\
French, German, Latin and Other Languages & 17 & $1.21 \%$ \\
International Relations & 18 & $1.11 \%$ \\
Area, Ethnic, and Civilization Studies & 19 & $1.10 \%$ \\
Pre-Law and Legal Studies & 19 & $0.99 \%$ \\
Marketing and Marketing Research & 20 & $0.93 \%$ \\
Electrical Engineering & 21 & $0.83 \%$ \\
Chemistry & 22 & $0.81 \%$ \\
Mathematics & 23 & $0.75 \%$ \\
Anthropology and Archeology & 24 & $0.67 \%$ \\
\hline Nor The & 25 & \\
\hline
\end{tabular}

Notes: The data are from the combined 2009-2013 American Community Survey. The sample includes persons ages 25-61 employed as lawyers. 
Table 2: Annual Earnings of U.S. Lawyers for the 25 Most Popular Majors

\begin{tabular}{|c|c|c|c|c|}
\hline Major & $\begin{array}{c}\text { Median } \\
\text { Earnings } \\
\text { Rank }\end{array}$ & $\begin{array}{l}\text { Median } \\
\text { Earnings }\end{array}$ & $\begin{array}{c}\text { Mean } \\
\text { Earnings } \\
\text { Rank }\end{array}$ & $\begin{array}{c}\text { Mean } \\
\text { Earnings }\end{array}$ \\
\hline Electrical Engineering & 1 & $\$ 179,744$ & 1 & $\$ 219,383$ \\
\hline Accounting & 2 & $\$ 135,044$ & 3 & $\$ 180,507$ \\
\hline Economics & 3 & $\$ 130,723$ & 2 & $\$ 182,359$ \\
\hline Finance & 4 & $\$ 122,150$ & 4 & $\$ 170,356$ \\
\hline Chemistry & 5 & $\$ 122,150$ & 6 & $\$ 165,266$ \\
\hline Mathematics & 6 & $\$ 122,008$ & 5 & $\$ 165,901$ \\
\hline International Relations & 7 & $\$ 119,829$ & 8 & $\$ 158,770$ \\
\hline History & 8 & $\$ 117,060$ & 7 & $\$ 161,682$ \\
\hline Political Science and Government & 9 & $\$ 114,288$ & 11 & $\$ 155,661$ \\
\hline Area, Ethnic, and Civilization Studies & 10 & $\$ 114,006$ & 12 & $\$ 155,475$ \\
\hline General Business & 11 & $\$ 111,971$ & 10 & $\$ 155,789$ \\
\hline Philosophy and Religious Studies & 12 & $\$ 110,354$ & 9 & $\$ 156,913$ \\
\hline Business Management and Administration & 13 & $\$ 107,178$ & 13 & $\$ 145,842$ \\
\hline Biology & 14 & $\$ 107,178$ & 16 & $\$ 139,439$ \\
\hline English Language and Literature & 15 & $\$ 106,881$ & 14 & $\$ 145,596$ \\
\hline Anthropology and Archeology & 16 & $\$ 105,863$ & 18 & $\$ 135,713$ \\
\hline Liberal Arts & 17 & $\$ 103,898$ & 15 & $\$ 143,480$ \\
\hline Communications & 18 & $\$ 101,791$ & 19 & $\$ 135,577$ \\
\hline Journalism & 19 & $\$ 100,774$ & 20 & $\$ 132,594$ \\
\hline Marketing and Marketing Research & 20 & $\$ 100,221$ & 17 & $\$ 138,274$ \\
\hline Psychology & 21 & $\$ 98,738$ & 21 & $\$ 129,328$ \\
\hline Sociology & 22 & $\$ 97,532$ & 23 & $\$ 126,028$ \\
\hline Pre-Law and Legal Studies & 23 & $\$ 93,508$ & 22 & $\$ 128,906$ \\
\hline French, German, Latin and Other Languages & 24 & $\$ 91,612$ & 24 & $\$ 123,823$ \\
\hline Criminal Justice and Fire Protection & 25 & $\$ 83,880$ & 25 & $\$ 113,681$ \\
\hline
\end{tabular}

Notes: The data are from the combined 2009-2013 American Community Survey. The earnings sample is restricted to persons ages 30-61 employed as lawyers. Earnings are adjusted for inflation and reported in 2015 dollars. 
Table 3: Median and OLS Regression Log Earnings Differences Relative To Economics Majors

\begin{tabular}{|c|c|c|}
\hline & $\begin{array}{c}\text { (1) } \\
\text { Median Regression }\end{array}$ & $\begin{array}{c}(2) \\
\text { OLS }\end{array}$ \\
\hline Electrical Engineering & $\begin{array}{c}0.230 * * * \\
(0.052)\end{array}$ & $\begin{array}{c}0.183^{* * * *} \\
(0.055)\end{array}$ \\
\hline Chemistry & $\begin{array}{c}0.072 \\
(0.053)\end{array}$ & $\begin{array}{l}-0.003 \\
(0.055)\end{array}$ \\
\hline Accounting & $\begin{array}{c}0.004 \\
(0.032)\end{array}$ & $\begin{array}{l}0.056^{*} \\
(0.033)\end{array}$ \\
\hline Mathematics & $\begin{array}{l}-0.012 \\
(0.056)\end{array}$ & $\begin{array}{c}0.032 \\
(0.059)\end{array}$ \\
\hline International Relations & $\begin{array}{l}-0.022 \\
(0.048)\end{array}$ & $\begin{array}{c}0.019 \\
(0.051)\end{array}$ \\
\hline Finance & $\begin{array}{l}-0.023 \\
(0.035)\end{array}$ & $\begin{array}{c}0.007 \\
(0.037)\end{array}$ \\
\hline Area, Ethnic, and Civilization Studies & $\begin{array}{c}-0.098 * * \\
(0.048)\end{array}$ & $\begin{array}{c}0.028 \\
(0.050)\end{array}$ \\
\hline Political Science and Government & $\begin{array}{c}-0.091 * * * \\
(0.020)\end{array}$ & $\begin{array}{c}-0.044 * * \\
(0.021)\end{array}$ \\
\hline History & $\begin{array}{c}-0.096 * * * \\
(0.023)\end{array}$ & $\begin{array}{c}-0.049 * * \\
(0.024)\end{array}$ \\
\hline Journalism & $\begin{array}{c}-0.098 * * \\
(0.041)\end{array}$ & $\begin{array}{c}-0.097 * * \\
(0.043)\end{array}$ \\
\hline General Business & $\begin{array}{c}-0.102 * * * \\
(0.032)\end{array}$ & $\begin{array}{c}-0.139 * * * \\
(0.033)\end{array}$ \\
\hline Biology & $\begin{array}{c}-0.106 * * * \\
(0.038)\end{array}$ & $\begin{array}{c}-0.113 * * * \\
(0.040)\end{array}$ \\
\hline English Language and Literature & $\begin{array}{c}-0.118 * * * \\
(0.024)\end{array}$ & $\begin{array}{c}-0.099 * * * \\
(0.025)\end{array}$ \\
\hline Anthropology and Archeology & $\begin{array}{c}-0.121 * * \\
(0.058)\end{array}$ & $\begin{array}{l}-0.106 * \\
(0.060)\end{array}$ \\
\hline Philosophy and Religious Studies & $\begin{array}{c}-0.132 * * * \\
(0.032)\end{array}$ & $\begin{array}{l}-0.059 * \\
(0.034)\end{array}$ \\
\hline Business Management and Administration & $\begin{array}{c}-0.132 * * * \\
(0.029)\end{array}$ & $\begin{array}{c}-0.105 * * * \\
(0.031)\end{array}$ \\
\hline Pre-Law and Legal Studies & $\begin{array}{c}-0.133 * * * \\
(0.046)\end{array}$ & $\begin{array}{c}-0.118 * * \\
(0.048)\end{array}$ \\
\hline Liberal Arts & $\begin{array}{c}-0.152 * * * \\
(0.042)\end{array}$ & $\begin{array}{c}-0.188 * * * \\
(0.044)\end{array}$ \\
\hline Marketing and Marketing Research & $\begin{array}{c}-0.161 * * * \\
(0.051)\end{array}$ & $\begin{array}{l}-0.101 * \\
(0.053)\end{array}$ \\
\hline Psychology & $\begin{array}{c}-0.183 * * * \\
(0.028)\end{array}$ & $\begin{array}{c}-0.154 * * * \\
(0.029)\end{array}$ \\
\hline Sociology & $\begin{array}{c}-0.195 * * * \\
(0.036)\end{array}$ & $\begin{array}{c}-0.141 * * * \\
(0.037)\end{array}$ \\
\hline French, German, Latin and Other Languages & $\begin{array}{c}-0.196 * * * \\
(0.045)\end{array}$ & $\begin{array}{c}-0.119 * * \\
(0.048)\end{array}$ \\
\hline Communications & $\begin{array}{c}-0.210 * * * \\
(0.037)\end{array}$ & $\begin{array}{c}-0.123 * * * \\
(0.039)\end{array}$ \\
\hline Criminal Justice and Fire Protection & $\begin{array}{c}-0.287 * * * \\
(0.034)\end{array}$ & $\begin{array}{c}-0.269 * * * \\
(0.035)\end{array}$ \\
\hline
\end{tabular}

Notes: The sample is restricted to persons ages 30-61 employed as lawyers with positive earnings, yielding 34,771 observations. Regressions include individual control variables for sex, race/ethnicity, age, survey year, and metropolitan area (or state residual) of current residence. Undergraduate economics majors are the base group against which coefficient estimate should be interpreted. *Significantly different from Economics at $10 \%$ level; **Significant at 5\%; ***Significant at $1 \%$. 